\title{
The quality of Valle del Belice sheep's milk and cheese produced in the hot summer season in Sicily
}

\section{Massimo Todaro, Adriana Bonanno \& Maria Luisa Scatassa}

Dairy Science \& Technology

Official journal of the Institut National de la Recherche Agronomique (INRA)Formerly 'Le Lait'

\section{ISSN 1958-5586}

Volume 94

Number 3

Dairy Sci. \& Technol. (2014) 94:225-239 DOI 10.1007/s13594-013-0155-0

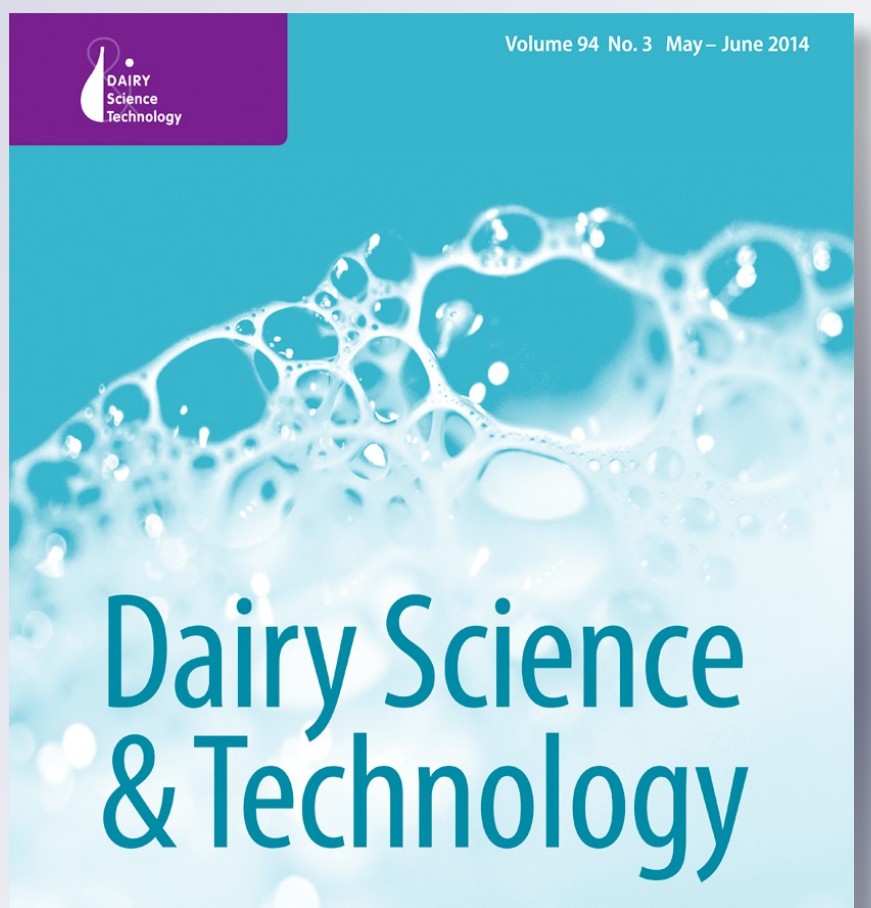

Formerly Le Lait

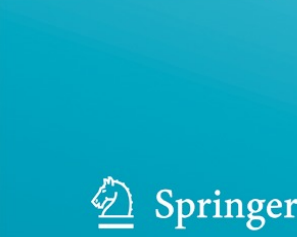

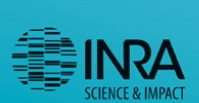


Your article is protected by copyright and all rights are held exclusively by INRA and Springer-Verlag France. This e-offprint is for personal use only and shall not be selfarchived in electronic repositories. If you wish to self-archive your article, please use the accepted manuscript version for posting on your own website. You may further deposit the accepted manuscript version in any repository, provided it is only made publicly available 12 months after official publication or later and provided acknowledgement is given to the original source of publication and a link is inserted to the published article on Springer's website. The link must be accompanied by the following text: "The final publication is available at link.springer.com". 


\title{
The quality of Valle del Belice sheep's milk and cheese produced in the hot summer season in Sicily
}

\author{
Massimo Todaro • Adriana Bonanno • \\ Maria Luisa Scatassa
}

Received: 8 August 2013 /Revised: 15 October 2013 / Accepted: 17 October 2013 /

Published online: 7 November 2013

(C) INRA and Springer-Verlag France 2013

\begin{abstract}
In response to the growing consumer demand for fresh cheese in summer, this investigation was aimed to evaluate the chemical and microbiological characteristics of sheep's milk and cheese produced in Sicily in the hot summer months. A total of 810 bulk milk samples collected from 17 farms rearing ewes of the Valle del Belice breed were analysed for chemical composition, somatic cell count, total bacterial count and clotting parameters. Samples $(n=18)$ of Protected Designation of Origin Vastedda della valle del Belice cheese produced in six dairies were collected in summer, autumn and spring and analysed for chemical composition, microbiological profile and fatty acid (FA) composition. Univariate and multivariate analyses were performed to assess variations by season. Sheep's milk produced in the summer had higher fat and casein contents, less lactose and urea and slightly higher total bacterial count and, similar to milk produced in winter, had a weaker clotting ability. Vastedda cheese produced in spring had less thermophilic lactococci and a high rumenic acid content. Cheese produced in summer had more fat; less saturated FA; and more linoleic acid, monounsaturated FA and omega-3 polyunsaturated FA. A dual approach to data analysis revealed a strong influence of production season on bulk milk and Vastedda cheese characteristics due to climate conditions and ewes' feeding regimen. Although this study provides evidence of the good nutritional properties of summer sheep's cheese, management and feeding strategies could aim to further improve the quality of milk and cheese produced in the summer months.
\end{abstract}

Keywords Summer sheep's milk $\cdot$ Valle del Belice ewes $\cdot$ Cheese fatty acids $\cdot$ Seasonal variation

\footnotetext{
M. Todaro $(\bowtie) \cdot$ A. Bonanno

Dipartimento Scienze Agrarie e Forestali, Università degli Studi di Palermo, viale delle Scienze

Palermo, Italy

e-mail: massimo.todaro@unipa.it
}

\section{L. Scatassa}

Istituto Zooprofilattico Sperimentale della Sicilia “A. Mirri”, via G. Marinuzzi, 4, Palermo, Italy 


\section{Introduction}

In farming systems based on grazing pasture, milk production frequently depends on climatic conditions and meteorological events that influence the quantity and quality of the pasture (Pulina et al. 2006).

Accordingly, in Sicily, the production of sheep's milk varies greatly throughout the year, essentially linked to the seasonal availability of grazed forage, on which periods of mating activity and lambing in turn depend.

Indeed, Sicilian sheep farming systems are based mainly on the extensive use of pasture, the availability and quality of which differ by season: pasture forages are green from October to mid-May, show maximum vegetative growth in spring corresponding to the more intense grazing activity and dry up in summer.

Nevertheless, sheep generally graze throughout the year (Bonanno et al. 2005). From November to June, grazing occurs on natural pastures, field crops at rest, meadows and swards of various species in pure or mixed culture. Often forage crops are grazed from December to March and then left undisturbed to devote their regrowth to hay. In summer, from July to September, crop residues, especially the stubble of threshed cereals, are the only grazed resources. When the available forage cannot meet ewes' need for fibre, the ewes receive a supplement of hay and/or straw. A farm or commercial concentrate $\left(400-800 \mathrm{~g}^{-\mathrm{day}^{-1}}\right.$.head $\left.{ }^{-1}\right)$ is provided to ewes in early lactation $(<100$ days in milking) and at the end of pregnancy ( $<20$ days).

The mating of Sicilian sheep traditionally begins in spring when pastures have the maximum available forage biomass. The main lambing period is thus in September and October, and a second lambing period occurs in winter, generally from December to February.

However, in some Sicilian environments, despite seasonal fluctuations in pasture feeding resources, the lambing distribution of sheep is less seasonal, because ewes mate in different periods of the year. This is the case in the valley of the Belice River, on the border of the Agrigento, Trapani and Palermo provinces, where the Valle del Belice breed originated and continues to be reared. Among Sicilian sheep breeds, the Valle del Belice produces the most milk (Giaccone et al. 2004), and this is the reason for its growing diffusion, which is in response to reductions in the number of heads of other breeds. In addition, lambing of Valle del Belice ewes takes place throughout the year, although most births occur in August (rather than September/October as for other Sicilian breeds) and then again in December and January (Giaccone et al. 2004). This lambing distribution results in a continuous production of milk throughout the year. However, the most milk is produced in spring, because of the abundant forage of pastures, and the least is produced in the summer months, when it is mostly given by ewes lambing from December to May and grazing mainly on crop residue supplemented with hay.

These characteristics of the Sicilian environment, and the presence of breeds able to produce milk throughout the year, enable producers to meet the strong demand for fresh sheep's cheese in the summer months, especially in hightourist areas.

As changes in the quality of dairy products result from many factors, including the seasonal climate and nutrition, the aim of the present study was to investigate characteristics of the quality of sheep's milk and cheese produced from Valle del Belice 
ewes in the hot summer season (June-August) by analysing its differences from milk and cheese produced during other seasons.

\section{Material and methods}

\subsection{Milk quality}

Seasonal variation in the quality of bulk sheep's milk was monitored for two consecutive years in 17 farms located in different areas of central-western Sicily and rearing Valle del Belice ewes: ten farms in the area of origin (four in Santa Margherita di Belice, two in Montevago, two in Sambuca di Sicilia and two in Menfi, in the province of Agrigento) and seven farms outside the area (three in Cammarata in the province of Agrigento; one in Lercara Friddi, one in Corleone, one in Godrano and one in Santa Cristina Gela, in the province of Palermo).

During the 2 years of the investigation, 810 samples of bulk milk were collected fortnightly immediately after the morning milking. After using a HI $9025 \mathrm{pH}-$ meter (Hanna Instruments, Ann Arbor, MI, USA) to determine $\mathrm{pH}$, the samples were transported at $4{ }^{\circ} \mathrm{C}$, without the addition of preservatives, to the milk laboratory at the Istituto Zooprofilattico Sperimentale della Sicilia 'A. Mirri'. Within $6 \mathrm{~h}$ of collection, samples were analysed for determination of lactose and fat (IDF 1990) and somatic cell count (SCC; IDF 1995) by the infrared method (Combifoss 6000, Foss Electric, Hillerød, Denmark); total bacterial count (TBC) by BactoScan instrument (Foss Electric); total nitrogen (TN), non-casein nitrogen (NCN) and non-protein nitrogen $(\mathrm{NPN}$; IDF 1964a, 1993), from which protein $(\mathrm{TN} \times 6.38)$, casein $((\mathrm{TN}-(\mathrm{NCN} \times 0.994)) \times 6.38)$ and whey protein $((\mathrm{NCN}-\mathrm{NPN}) \times 6.38)$ were calculated; freezing point using an Astor Cryoscope 4000 SE; titratable acidity by the SoxhletHenkel method ( ${ }^{\circ} \mathrm{SH} .100 \mathrm{~mL}^{-1}$ ); urea by the enzymatic method using the difference in pH (CL-10 Plus, Eurochem, Roma, Italy); and milk clotting ability by measuring, according to Zannoni and Annibaldi (1981), the clotting time ( $r$, min), curd firming time $\left(k_{20}, \mathrm{~min}\right)$ and curd firmness after $30 \mathrm{~min}\left(a_{30}, \mathrm{~mm}\right)$ of $10 \mathrm{~mL}$ milk at $35^{\circ} \mathrm{C}$ with $0.2 \mathrm{~mL}$ of a diluted solution (1.6:100) of rennet (1:15,000; Chr. Hansen, Parma, Italy), using the Formagraph (Foss Electric).

\subsection{Cheese quality}

Eighteen samples of protected designation of origin (PDO) Vastedda della valle del Belice cheese produced in six different dairies in three seasons (summer (June), autumn (November) and spring (April)) were analysed. PDO Vastedda della valle del Belice is a Sicilian pasta filata sheep's cheese made from raw milk without starter addition and is traditionally consumed fresh, a few days after manufacture. The details of its production have been reported by Mucchetti et al. (2008).

Samples of the cheese were analysed for dry matter $(\mathrm{DM})$, fat, protein $(\mathrm{TN} \times 6.38)$, ash and $\mathrm{NaCl}$ content according to IDF standards (4A (IDF 1982), 5B (IDF 1986), 25 (IDF 1964b), 27 (IDF 1964c) and 17A (IDF 1972), respectively).

For microbiological analyses, samples were homogenised in a sodium citrate $(2 \%$, $w / v$ ) solution (cheese/diluents, 1:9) by means of a stomacher (Laboratory Blender 
Stomacher 400, Seward, Worthing, England) for $2 \mathrm{~min}$ at the highest speed. Further decimal dilutions were prepared in Ringer's solution (Oxoid, Milan, Italy). Cell suspensions were plated and incubated as follows: total mesophilic count on plate count agar plus 1 g. $\mathrm{L}^{-1}$ skimmed milk, incubated aerobically at $30{ }^{\circ} \mathrm{C}$ for $72 \mathrm{~h}$; mesophilic rod lactic acid bacteria (LAB) on de Man-Rogosa-Sharpe agar, acidified at pH 5.4 with lactic acid $(5 \mathrm{M})$, incubated anaerobically at $37^{\circ} \mathrm{C}$ for $72 \mathrm{~h}$; mesophilic coccus LAB on M17 agar, incubated anaerobically at $30{ }^{\circ} \mathrm{C}$ for $72 \mathrm{~h}$; thermophilic coccus LAB on M17 agar, incubated anaerobically at $44{ }^{\circ} \mathrm{C}$ for $72 \mathrm{~h}$; and enterococci on kanamycin aesculin azide agar, incubated aerobically at $37{ }^{\circ} \mathrm{C}$ for $24 \mathrm{~h}$. All media were purchased from Oxoid. Microbiological counts were performed in triplicate.

Fatty acids (FAs) in lyophilised cheese samples (100 mg) were methylated directly with $2 \mathrm{~mL} 0.5 \mathrm{M} \mathrm{NaOCH}_{3}$ at $50{ }^{\circ} \mathrm{C}$ for $15 \mathrm{~min}$, followed by $1 \mathrm{~mL} 5 \%$ $\mathrm{HCl}$ in methanol at $50{ }^{\circ} \mathrm{C}$ for $15 \mathrm{~min}$ (Loor et al. 2002). Fatty acid methyl esters (FAMEs) were recovered in hexane $(1.5 \mathrm{~mL})$. Then $1 \mu \mathrm{L}$ of each sample was injected by autosampler into an HP 6890 GC system equipped with a flame ionisation detector (Agilent Technologies, Santa Clara, CA, USA). FAMEs from all samples were separated using a $0.25-\mu \mathrm{m}$ fused Mega10 capillary column $100 \mathrm{~m}$ in length with a $0.25-\mathrm{mm}$ internal diameter (CP-Sil 88; Chrompack, Middelburg, The Netherlands). The injector temperature was kept at $250{ }^{\circ} \mathrm{C}$ and the detector temperature was kept at $240{ }^{\circ} \mathrm{C}$ with an $\mathrm{H}_{2}$ flow of $40 \mathrm{~mL} \cdot \mathrm{min}^{-1}$, an air flow of $400 \mathrm{~mL} \cdot \mathrm{min}^{-1}$ and a constant helium makeup flow of $45 \mathrm{~mL} \cdot \mathrm{min}^{-1}$. The initial oven temperature was held at $70{ }^{\circ} \mathrm{C}$ for $1 \mathrm{~min}$, increased $5{ }^{\circ} \mathrm{C} / \mathrm{min}$ to $100{ }^{\circ} \mathrm{C}$ (held for $2 \mathrm{~min}$ ), then increased $10{ }^{\circ} \mathrm{C} \cdot \mathrm{min}^{-1}$ to $175{ }^{\circ} \mathrm{C}$ (held for $40 \mathrm{~min}$ ) and $5^{\circ} \mathrm{C} \cdot \mathrm{min}^{-1}$ to a final temperature of $225{ }^{\circ} \mathrm{C}$ (held for $25 \mathrm{~min}$ ). Helium was the carrier gas, with a head pressure of $23 \mathrm{psi}$ and a flow rate of $0.7 \mathrm{~mL} \cdot \mathrm{min}^{-1}$ (linear velocity $=14 \mathrm{~cm} . \mathrm{s}^{-1}$ ). FAME hexane mix solution $\mathrm{C} 4-\mathrm{C} 24$ (Supelco, Bellafonte, PA, USA) was used to identify each FA. Isomers of conjugated linoleic acid (CLA) were identified using a commercial mixture of cis- and trans-9,11- and 10,12-ocdecadienoic acid methyl esters (Sigma-Aldrich, Milano, Italy). Total FA was quantified using C23:0 (Sigma-Aldrich) as an internal standard, which was added to each sample at a concentration of $4 \mathrm{mg} \cdot \mathrm{g}^{-1}$ lyophilised cheese. The Health Promoting Index was calculated as suggested by Chen et al. (2004): total unsaturated $\mathrm{FA} /(\mathrm{C} 12: 0+(4 \times \mathrm{C} 14: 0)+\mathrm{C} 16: 0)$.

\subsection{Statistical analysis}

The GLM and CANDISC procedures of SAS Version 9.2 (SAS 2010) were used for the statistical analysis.

Milk quality was analysed using the GLM procedure for both month of sampling and season of production, considering herd (1-17), year of production (two levels) and month of sampling (11 levels: July and August were combined because of the small number of observations) or season of production (summer: June (64), July (44) and August (6); autumn: September (39), October (81), November (87) and December (78); winter: January (80), February (81) and March (77); and spring: April (77) and May (96)) as fixed factors. SCC and TBC were transformed into logarithmic form $\left(\log _{10}\right)$. 
The least square means (LSM) for the month of sampling were used to describe the trend in milk quality. The GLM procedure for cheese quality data considered two factors: season (autumn, spring and summer) and dairy (1-6). The LSM were compared using Student's $t$ test.

Then, to ascertain the discriminant effect of the season of production on cheese quality, microbiological, chemical and FA parameters were analysed with a multivariate approach by canonical discriminant analysis.

\section{Results and discussion}

\subsection{Milk quality}

The season of production significantly affected all quality traits of milk from the Valle del Belice ewes (Table 1).

The milk SCC was high in all seasons, which is typical for Sicilian breeds. Levels decreased in spring, especially in May (Fig. 1a), but higher levels were observed in several months, including July and August. The TBC, which reflects the hygienic condition of the milk production environment, was around 500,000 CFU.mL ${ }^{-1}$; it was significantly higher in summer, especially in June, and lower in spring, although in a limited extent (Table 1; Fig. 1a).

Table 1 Effects of production season on bulk milk quality (LSM \pm SE)

\begin{tabular}{|c|c|c|c|c|c|}
\hline Item & Summer & Autumn & Winter & Spring & Significance \\
\hline Samples (n) & 114 & 285 & 238 & 173 & \\
\hline Somatic cell count (log) & $6.16 \pm 0.04 \mathrm{Aab}$ & $6.19 \pm 0.03 \mathrm{Aa}$ & $6.11 \pm 0.03 \mathrm{ABb}$ & $6.02 \pm 0.04 \mathrm{Bc}$ & $* * *$ \\
\hline Total bacterial count $(\log )$ & $5.70 \pm 0.03 \mathrm{~A}$ & $5.60 \pm 0.02 \mathrm{~B}$ & $5.56 \pm 0.02 \mathrm{~B}$ & $5.46 \pm 0.04 \mathrm{C}$ & $* * *$ \\
\hline Fat $(\%)$ & $7.77 \pm 0.09 \mathrm{~A}$ & $7.00 \pm 0.05 \mathrm{~B}$ & $7.02 \pm 0.06 \mathrm{~B}$ & $6.53 \pm 0.07 \mathrm{C}$ & $* * *$ \\
\hline Lactose $(\%)$ & $4.34 \pm 0.02 \mathrm{C}$ & $4.61 \pm 0.01 \mathrm{~B}$ & $4.65 \pm 0.01 \mathrm{~A}$ & $4.61 \pm 0.01 \mathrm{~B}$ & $* * *$ \\
\hline Protein $(\%)$ & $6.14 \pm 0.05 \mathrm{~A}$ & $5.83 \pm 0.03 \mathrm{~B}$ & $6.17 \pm 0.03 \mathrm{~A}$ & $5.84 \pm 0.04 \mathrm{~B}$ & $* * *$ \\
\hline Casein $(\%)$ & $4.75 \pm 0.04 \mathrm{~A}$ & $4.52 \pm 0.02 \mathrm{~B}$ & $4.74 \pm 0.02 \mathrm{~A}$ & $4.56 \pm 0.03 \mathrm{~B}$ & $* * *$ \\
\hline Whey protein $(\%)$ & $1.39 \pm 0.02 \mathrm{~A}$ & $1.31 \pm 0.01 \mathrm{~B}$ & $1.43 \pm 0.01 \mathrm{~A}$ & $1.28 \pm 0.01 \mathrm{~B}$ & $* * *$ \\
\hline Urea $\left(\mathrm{mg} \cdot \mathrm{dL}^{-1}\right)$ & $26.38 \pm 0.89 \mathrm{C}$ & $35.95 \pm 0.58 \mathrm{~B}$ & $43.34 \pm 0.61 \mathrm{~A}$ & $36.17 \pm 0.72 \mathrm{~B}$ & $* * *$ \\
\hline $\mathrm{pH}$ & $6.52 \pm 0.02 \mathrm{C}$ & $6.60 \pm 0.01 \mathrm{~B}$ & $6.63 \pm 0.01 \mathrm{~A}$ & $6.54 \pm 0.02 \mathrm{C}$ & $* * *$ \\
\hline $\begin{array}{l}\text { Titratable acidity } \\
\quad\left({ }^{\circ} \mathrm{SH} .100 \mathrm{~mL}^{-1}\right)\end{array}$ & $9.60 \pm 0.25 \mathrm{~B}$ & $10.46 \pm 0.16 \mathrm{~A}$ & $9.67 \pm 0.17 \mathrm{~B}$ & $9.67 \pm 0.21 \mathrm{~B}$ & $* * *$ \\
\hline Freezing point $\left({ }^{\circ} \mathrm{C}\right)$ & $-0.559 \pm 0.001 \mathrm{~B}$ & $-0.559 \pm 0.001 \mathrm{~B}$ & $-0.563 \pm 0.001 \mathrm{~A}$ & $-0.562 \pm 0.001 \mathrm{AB}$ & $* * *$ \\
\hline Clotting time $(r, \min )$ & $22.80 \pm 0.70 \mathrm{~A}$ & $21.10 \pm 0.41 \mathrm{~B}$ & $23.29 \pm 0.55 \mathrm{~A}$ & $20.11 \pm 0.48 \mathrm{~B}$ & $* * *$ \\
\hline Curd firming time $\left(k_{20}, \mathrm{~min}\right)$ & $1.84 \pm 0.13 \mathrm{AB}$ & $2.13 \pm 0.08 \mathrm{~A}$ & $1.66 \pm 0.11 \mathrm{~B}$ & $1.79 \pm 0.09 \mathrm{~B}$ & $* * *$ \\
\hline Curd firmness $\left(a_{30}, \mathrm{~mm}\right)$ & $28.44 \pm 1.33$ B & $33.71 \pm 0.79 \mathrm{~A}$ & $29.49 \pm 1.05 \mathrm{~B}$ & $34.21 \pm 0.91 \mathrm{~A}$ & $* * *$ \\
\hline Rennet reactive samples (\%) & $59 \pm 4.2 \mathrm{~B}$ & $77 \pm 2.9 \mathrm{~A}$ & $47 \pm 3.0 \mathrm{C}$ & $83 \pm 3.4 \mathrm{~A}$ & $* * *$ \\
\hline
\end{tabular}

Summer: June, July and August; autumn: September, October, November and December; winter: January, February and March; spring: April and May. Means within a row with different letters differ (A-C; $P \leq 0.01)$; means within a row with different letters differ $(\mathrm{a}-\mathrm{c} ; P \leq 0.05)$.

$* * * P \leq 0.001$ 
a

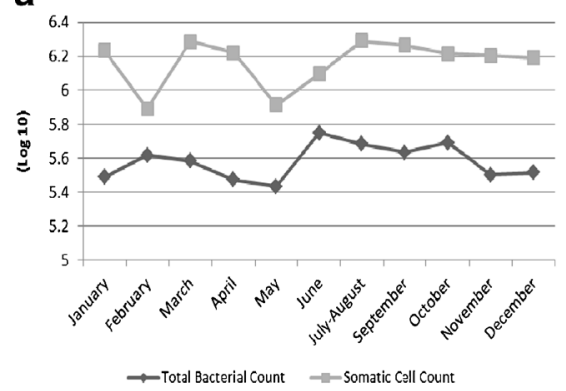

C

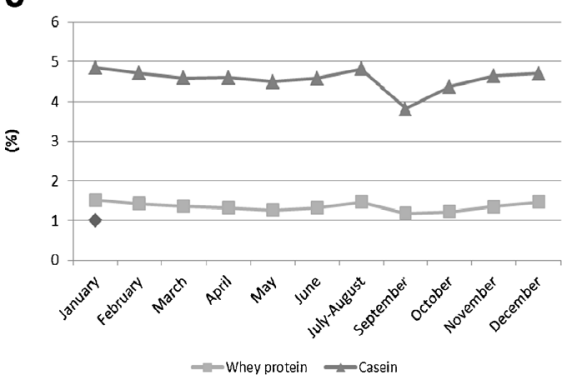

e

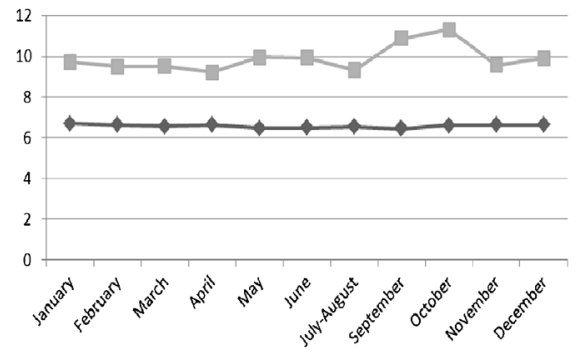

$\leadsto \mathrm{pH}=-$ Tit. acidity b

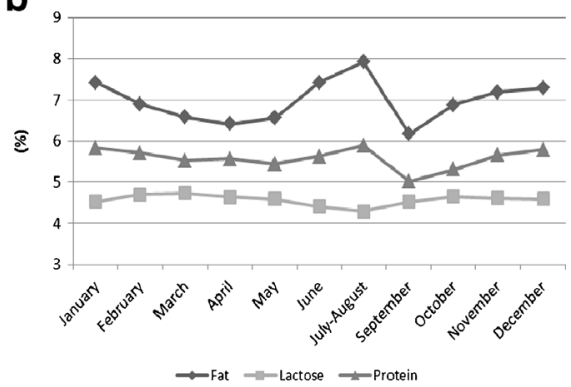

d
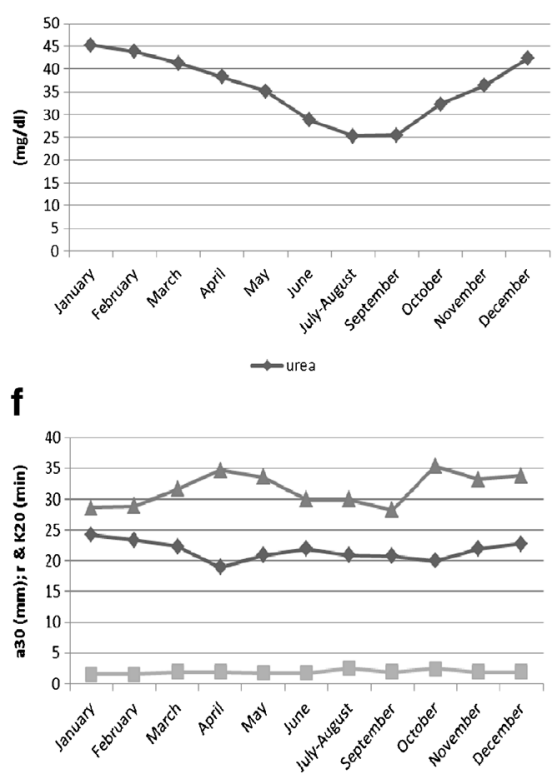

$\rightarrow 1=-k 20=230$

Fig. 1 Monthly variation in TBC and somatic cell count (a); fat, lactose and protein (b); whey protein and casein (c); urea (d); pH and titratable acidity (e); and clotting ability (f) in sheep's milk

The increase in SCC from spring to summer can be explained by a concentration effect due to the lower milk yield at the end of lactation, in accordance with Morgante et al. (1996) and Bianchi et al. (2004). However, it may also be due to heat stress provoked by high environmental temperatures, in accordance with other authors (Finocchiaro et al. 2007; Peana et al. 2007; Di Grigoli et al. 2009). In addition, the slight increase in TBC can be explained by the higher environmental temperatures in summer, which result in faster multiplication of microorganisms (Albenzio et al. 2002).

The milk's fat content was significantly higher in summer but markedly reduced in spring (Table 1). Monthly levels of fat showed a decreasing trend from January to April, and then rose rapidly until reaching a maximum value in July/August (Fig. 1b).

By contrast, the percentage of lactose was lower in summer (Table 1) and varied slightly as a function of month (Fig. 1b). 
Protein, casein and whey protein contents were higher in samples of summer and winter milk (Table 1). The highest values were recorded in July and August, and then in December and January (Fig. 1b, c).

Therefore, in July/August, milk showed an increase in fat, protein, casein and whey protein and a reduction in lactose. Given that in these months most ewes are in an advanced phase of lactation, these variations can be linked to the progression of lactation, which is characterised by a gradual reduction in milk yield, resulting in a concentration of milk components (Fuertes et al. 1998; Sevi et al. 2000, 2004; Jaramillo et al. 2008). The ewes' diet at pasture in the summer period, which was based on dry and fibrous forage, was also responsible for the increased milk fat level (CappioBorlino et al. 1997). Moreover, the reduction in lactose, which occurs as lactation progresses (Sevi et al. 2004), may be due to a worsening of udder health (Sevi et al. 1999), as a progressive deterioration of ewe udder health in late lactation has been documented (Fthenakis 1994). Lactose is the main osmotically active component in milk, and its content remains substantially unchanged during lactation in healthy animals. However, in animals with mastitis (even subclinical mastitis), lactose synthesis decreases and lactose is partially substituted as an osmotic component of milk by other elements, primarily chlorides (Kalantzopoulos 1994).

Milk urea content was higher in winter and lower in summer (Table 1). In general, it showed a gradual decrease from December/January to July/August and September, when the lowest urea levels were reached, and then rose again (Fig. 1d). Milk urea reached higher than $35 \mathrm{mg} \cdot \mathrm{dL}^{-1}$, considered an acceptable level for dairy ewes (Cannas et al. 1998), from November to April. The major determinants of urea formation are the amount of daily crude protein intake and the dietary ratio of crude protein to energy. A relationship between milk urea and dietary crude protein has been found in dairy cows (Schepers and Meijer 1998; Jonker et al. 1999; Nousiainen et al. 2004), ewes (Cannas et al. 1998) and goats (Bonanno et al. 2008), and thus milk urea is considered a fundamental nutritional tool for ruminant species. In this investigation, the increase in milk urea observed from November to April can be linked to the availability of young pastures, which are particularly abundant in spring, and which are rich in crude protein that is often not well balanced by an energy supplement. In contrast, a reduction in milk urea occurred in summer, when ewes graze on dry forage characterised by a low crude protein content.

Milk pH changed little throughout the year (Fig. 1e), although it was lower in summer and spring (Table 1). By contrast, titratable acidity was significantly higher in September and October (Fig. 1e), contributing to an increased average value in autumn (Table 1). This result can be explained by the large number of ewes lambed in August that were thus in early lactation, a phase characterised by higher milk acidity than successive phases of lactation (Pulina and Nudda 2002). The freezing point showed slight but significant differences by season.

On the whole, the coagulation properties of milk improved in spring, when a lower coagulation time $(r)$ was associated with rapid curd firming $\left(k_{20}\right)$ and high curd consistency $\left(a_{30}\right)$. Furthermore, the trend for milk clotting parameters showed that curd firming time $\left(k_{20}\right)$ did not fluctuate markedly, although milk produced in the summer and winter months had worse coagulation properties because of an increase in clotting time $(r)$ and a reduction in curd firmness $\left(a_{30}\right.$; Fig. 1f). However, the rennet reactive milk samples were significantly lower in summer and winter than in the other seasons (Table 1).

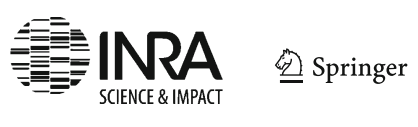


Table 2 Effects of production season on the microbiological profile (log cfu.mL ${ }^{-1}$ ) of cheese from milk of Valle del Belice ewes (LSM \pm SE)

\begin{tabular}{lllll}
\hline Item & Summer & Autumn & Spring & Significance \\
\hline Total mesophilic count & $7.66 \pm 0.18$ & $8.11 \pm 0.21$ & $7.61 \pm 0.23$ & $\mathrm{~ns}$ \\
Enterococci & $4.67 \pm 0.38$ & $5.97 \pm 0.45$ & $5.77 \pm 0.50$ & $\mathrm{~ns}$ \\
Thermophilic coccus LAB & $8.55 \pm 0.28 \mathrm{a}$ & $8.49 \pm 0.33 \mathrm{a}$ & $7.34 \pm 0.37 \mathrm{~b}$ & $*$ \\
Mesophilic coccus LAB & $7.36 \pm 0.34$ & $8.08 \pm 0.39$ & $7.14 \pm 0.44$ & $\mathrm{~ns}$ \\
Mesophilic rod coccus & $7.96 \pm 0.37$ & $8.00 \pm 0.44$ & $8.52 \pm 0.49$ & $\mathrm{~ns}$ \\
\hline
\end{tabular}

Means within a row with different letters differ ( $\mathrm{a}$ and $\mathrm{b} ; P \leq 0.05$ )

$n s$ not significant

$* P \leq 0.05$

With regard to summer, these results are in agreement with the decrease in cheesemaking efficiency observed in late lactation by Pulina et al. (2006). However, the worsening of milk clotting ability could be due to the increased SCC detected in July and August as an effect of both late lactation and heat stress. Some endogenous proteolytic enzymes, including plasmin, cathepsin D and elastase, are secreted from somatic cells and are active in the disruption of intact casein, thus impairing milk coagulation properties and reducing cheese yield (Albenzio et al. 2009).

Ultimately, the present results confirm how the season greatly affects the quality of milk produced by sheep fed mainly at pasture for most of the year, as are these Valle del Belice ewes. In addition, these results show how the quality of summer milk is different from that of milk produced in other seasons as a consequence of climatic and nutritional conditions, stage of lactation and lambing distribution (Carta et al. 1995; Maria and Gabina 1993; Matutinovic et al. 2011; Sevi et al. 2004). However, although summer saw an increase in SCC and TBC levels and a reduction in clotting ability, it also saw improved fat and casein levels, which are particularly relevant for sheep's milk that is destined to for cheese-making.

Table 3 Effects of production season on the chemical composition of cheese from milk of Valle del Belice ewes $(\mathrm{LSM} \pm \mathrm{SE})$

\begin{tabular}{lcccc}
\hline Item & Summer & Autumn & Spring & Significance \\
\hline Dry matter (DM; \%) & $51.94 \pm 0.68$ & $54.34 \pm 0.80$ & $53.44 \pm 0.89$ & $\mathrm{~ns}$ \\
Fat (\% on DM) & $44.86 \pm 0.30 \mathrm{~A}$ & $43.12 \pm 0.35 \mathrm{~B}$ & $43.93 \pm 0.39 \mathrm{AB}$ & $* *$ \\
Protein (\% on DM) & $42.58 \pm 0.66$ & $40.78 \pm 0.68$ & $42.97 \pm 0.87$ & $\mathrm{~ns}$ \\
Salt (\% on DM) & $2.96 \pm 0.12$ & $3.04 \pm 0.14$ & $3.20 \pm 0.15$ & $\mathrm{~ns}$ \\
Ash (\% on DM) & $7.18 \pm 0.15$ & $6.72 \pm 0.18$ & $6.91 \pm 0.20$ & $\mathrm{~ns}$ \\
\hline
\end{tabular}

Means within a row with different letters differ (A and $\mathrm{B} ; P \leq 0.01)$

$n s$ not significant

$* * P \leq 0.01$ 
Table 4 Effects of production season on the fatty acid composition (g.100 g fat) of cheese from milk of Valle del Belice ewes (LSM \pm SE)

\begin{tabular}{|c|c|c|c|c|}
\hline Item & Summer & Autumn & Spring & Significance \\
\hline $\mathrm{C} 8: 0$ & $2.38 \pm 0.11$ & $2.69 \pm 0.13$ & $2.30 \pm 0.15$ & ns \\
\hline C10:0 & $5.75 \pm 0.51 \mathrm{~B}$ & $6.72 \pm 0.60 \mathrm{~B}$ & $8.94 \pm 0.67 \mathrm{~A}$ & $* *$ \\
\hline $\mathrm{C} 12: 0$ & $4.19 \pm 0.14 \mathrm{C}$ & $5.43 \pm 0.16 \mathrm{~A}$ & $4.67 \pm 0.18 \mathrm{~B}$ & $* * *$ \\
\hline $\mathrm{C} 14: 0$ & $9.89 \pm 0.26 \mathrm{c}$ & $11.06 \pm 0.31 \mathrm{~b}$ & $12.11 \pm 0.34 \mathrm{a}$ & $* *$ \\
\hline $\mathrm{C} 14: 1$ & $0.15 \pm 0.01 \mathrm{~A}$ & $0.16 \pm 0.01 \mathrm{~A}$ & $0.09 \pm 0.01 \mathrm{~B}$ & $* *$ \\
\hline $\mathrm{C} 16: 0$ & $16.20 \pm 0.51$ & $16.46 \pm 0.60$ & $16.65 \pm 0.68$ & ns \\
\hline C16:1 & $1.04 \pm 0.05 \mathrm{~A}$ & $1.03 \pm 0.06 \mathrm{~A}$ & $0.69 \pm 0.07 \mathrm{~B}$ & $* *$ \\
\hline $\mathrm{C} 17: 0$ & $0.49 \pm 0.03 \mathrm{~A}$ & $0.32 \pm 0.04 \mathrm{~B}$ & $0.20 \pm 0.04 \mathrm{C}$ & $* * *$ \\
\hline $\mathrm{C} 17: 1$ & $0.32 \pm 0.02 \mathrm{~A}$ & $0.20 \pm 0.02 \mathrm{~B}$ & $0.15 \pm 0.03 \mathrm{~B}$ & $* *$ \\
\hline C18:0 & $6.43 \pm 0.62$ & $7.35 \pm 0.73$ & $7.84 \pm 0.82$ & ns \\
\hline $\mathrm{C} 18: 1 c 9$ & $27.76 \pm 1.33 \mathrm{~A}$ & $27.03 \pm 1.56 \mathrm{~A}$ & $18.62 \pm 1.75 \mathrm{~B}$ & $* *$ \\
\hline $\mathrm{C} 18: 2 \mathrm{n}-6 \mathrm{c} 9 \mathrm{c12}$ & $4.05 \pm 0.22 \mathrm{a}$ & $2.88 \pm 0.26 \mathrm{~b}$ & $3.18 \pm 0.29 b$ & $*$ \\
\hline C18:3 n-3 $\alpha$-linolenic & $2.46 \pm 0.31$ & $2.82 \pm 0.36$ & $3.05 \pm 0.40$ & ns \\
\hline CLA C18:2 $c 9 t 11, \mathrm{RA}$ & $0.53 \pm 0.07 \mathrm{~B}$ & $0.38 \pm 0.08 \mathrm{~B}$ & $0.84 \pm 0.09 \mathrm{~A}$ & $* *$ \\
\hline $\mathrm{C} 20: 0$ & $0.17 \pm 0.02 \mathrm{~A}$ & $0.11 \pm 0.02 \mathrm{AB}$ & $0.05 \pm 0.03 \mathrm{~B}$ & $*$ \\
\hline $\mathrm{C} 20: 5 n-3, \mathrm{EPA}$ & $0.19 \pm 0.02 \mathrm{~A}$ & $0.15 \pm 0.02 \mathrm{AB}$ & $0.10 \pm 0.02 \mathrm{~B}$ & $*$ \\
\hline $\mathrm{C} 22: 5 n-3, \mathrm{DPA}$ & $0.88 \pm 0.02 \mathrm{~A}$ & $0.55 \pm 0.03 \mathrm{~B}$ & $0.15 \pm 0.03 \mathrm{C}$ & $* * *$ \\
\hline C22:6 n-3, DHA & $0.11 \pm 0.01 \mathrm{~A}$ & $0.05 \pm 0.01 \mathrm{~B}$ & $0.05 \pm 0.01 \mathrm{~B}$ & $* *$ \\
\hline$\sum_{\mathrm{SFA}}$ & $45.34 \pm 1.22 \mathrm{~B}$ & $50.03 \pm 1.43 \mathrm{~A}$ & $52.71 \pm 1.60 \mathrm{~A}$ & $*$ \\
\hline$\sum_{\text {MUFA }}$ & $29.26 \pm 1.36 \mathrm{~A}$ & $28.41 \pm 1.59 \mathrm{~A}$ & $19.54 \pm 1.78 \mathrm{~B}$ & $* *$ \\
\hline$\sum_{\text {PUFA }}$ & $7.85 \pm 0.47$ & $6.56 \pm 0.55$ & $6.59 \pm 0.61$ & ns \\
\hline$\sum_{\mathrm{SFA}} / \sum_{\mathrm{UFA}}$ & $1.21 \pm 0.11 \mathrm{~B}$ & $1.44 \pm 0.13 \mathrm{~B}$ & $2.07 \pm 0.15 \mathrm{~A}$ & $* *$ \\
\hline$\sum_{\text {omega-6 }} / \sum_{\text {omega-3 }}$ & $1.12 \pm 0.08 \mathrm{a}$ & $0.81 \pm 0.10 \mathrm{~b}$ & $1.05 \pm 0.11 \mathrm{ab}$ & $*$ \\
\hline Health-Promoting Index ${ }^{a}$ & $0.62 \pm 0.08 \mathrm{~A}$ & $0.53 \pm 0.03 \mathrm{~B}$ & $0.37 \pm 0.03 \mathrm{C}$ & $* * *$ \\
\hline
\end{tabular}

Means within a row with different letters differ $(\mathrm{A}-\mathrm{C} ; P \leq 0.01)$. Means within a row with different letters differ $(\mathrm{a}-\mathrm{c} ; P \leq 0.05)$

$n s$ not significant, $R A$ rumenic acid, EPA eicosapentaenoic acid, DPA docosapentaenoic acid, DHA docosahexaenoic acid

$* P \leq 0.05 ; * * P \leq 0.01 ; * * * P \leq 0.001$

${ }^{a}$ Health-Promoting Index $=$ unsaturated FA/ $(\mathrm{C} 12: 0+(4 \times \mathrm{C} 14: 0)+\mathrm{C} 16: 0)($ Chen et al. 2004)

\subsection{Cheese quality}

Table 2 shows the LSM for the microbiological profile of PDO Vastedda della valle del Belice cheese by season of production. The cheese showed significant differences in the amount of thermophilic lactococci only, such that cheese produced in spring had lower values than cheese produced in the other seasons. All cheese was high in LAB, and the slight variations observed by season could be related to differences in indigenous endogenous and exogenous microflora of each specific condition of production, especially the environmental temperature. 


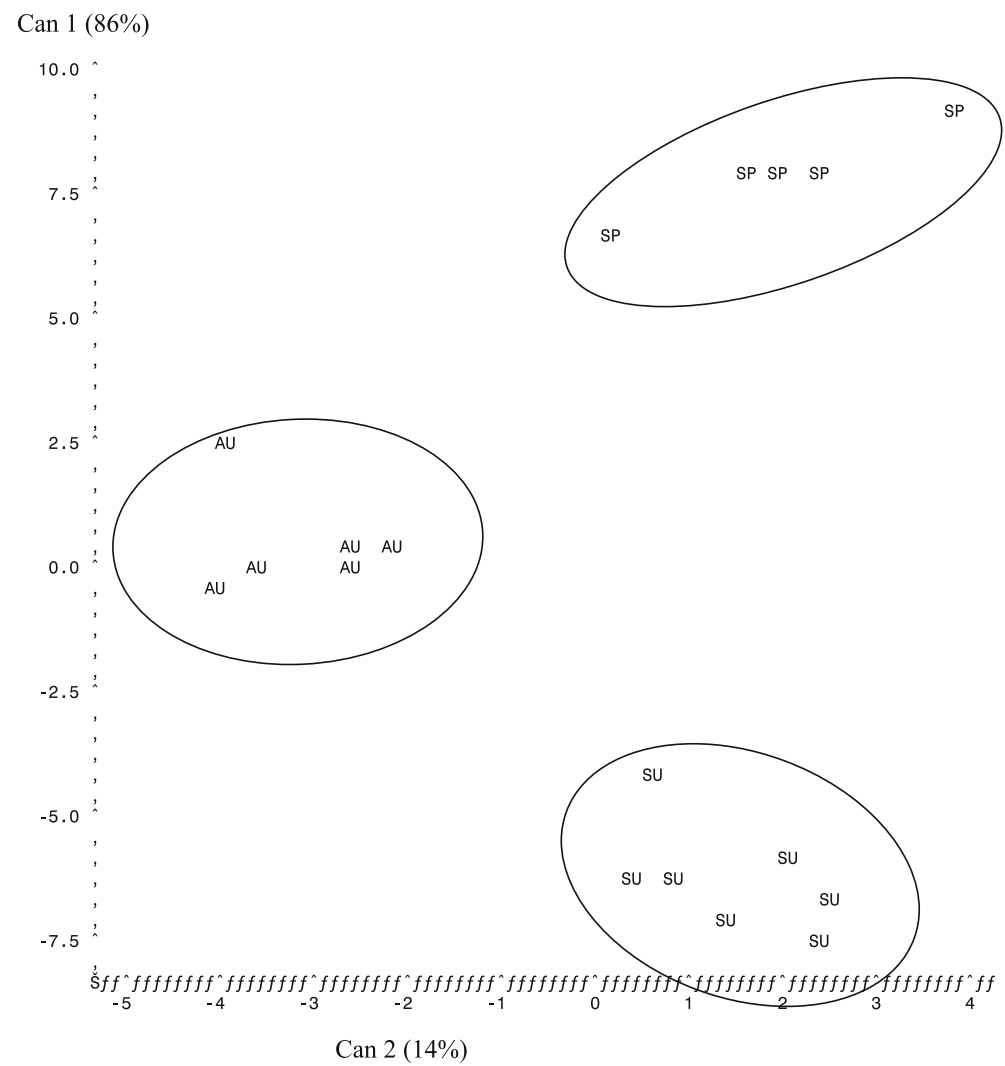

Fig. 2 Cheese distribution by production season using the canonical 1 and canonical 2 discriminant functions. $S U$ Summer, $A U$ Autumn, SP Spring

The LSM of chemical parameters of the Vastedda cheese are shown in Table 3. The cheese differed only in terms of fat percentage, which was significantly higher in the Vastedda cheese produced in summer. No statistically significant difference was found for the percentages of protein, salt or ash. The higher fat in summer cheese is certainly linked to the higher percentage of fat observed in summer milk, in turn a result of milk concentration in late lactation and the high level of fibre in the ewes' diet.

The FA composition of cheese fat differed significantly by season (Table 4). The data showed an immediate difference in Vastedda cheese produced in summer from cheese produced in the other seasons. The summer cheese had less saturated FA (SFA), especially $\mathrm{C} 10: 0, \mathrm{C} 12: 0$ and $\mathrm{C} 14: 0$, than cheese produced in the other seasons. Monounsaturated FA (MUFA) was higher in both summer and autumn cheese because of the increased amount of oleic acid (C18:1 c 9 ). No difference was found for the total amount of polyunsaturated FA (PUFA), although it was higher in summer than in the other seasons. However, the summer cheese was higher in linoleic acid (C18:2 n-6), which contributed to an increase in the omega-6/omega-3 ratio despite the higher amounts of omega-3 PUFA, such as EPA, DPA and DHA, a finding that is of particular interest from a nutritional point of view. The amount of rumenic acid (RA; C18:2 $c 9 t 11)$, the most abundant of the CLA isomers, was statistically higher in Vastedda cheese produced in spring than in 
Table 5 Canonical discriminant analysis: Mahalanobis quadratic distances among 18 cheeses produced in different seasons

$* P<0.05$

\begin{tabular}{lcrr}
\hline Season & Summer & Autumn & Spring \\
\hline Summer & 1 & 67 & $200^{*}$ \\
Autumn & & 1 & 81 \\
Spring & & & 1 \\
\hline
\end{tabular}

cheese produced in the other seasons. As for the Health Promoting Index, which expresses the health value of dietary fat (Chen et al. 2004), higher values were found in the summer cheese.

Therefore, the season of production had a marked effect on cheese FA composition. The higher RA content in cheese produced in spring reflects the strong effects of the green pasture in the ewes' diet in this season (Cabiddu et al. 2005; Dewhurst et al. 2003; Nudda et al. 2005). In general, when the amount of green forage increases in the diet of ruminants, the high $\alpha$-linolenic acid (C18:3 n-3) content is partly biohydrogenated into vaccenic acid (VA, C18:1 t11) and partly absorbed by the intestine and secreted into the milk. Furthermore, VA is partly converted into RA in the mammary gland by the $\Delta-9$ desaturase enzyme (Antongiovanni et al. 2003; Bauman et al. 2006). RA has beneficial effects on human health that, because of its cytotoxic action against several tumour cell lines, mainly contribute to preventing the occurrence of tumours (Parodi 1999; Banni et al. 2002). RA also has antioxidant and antiatherogenic properties and is involved in the control of diabetes, osteogenesis, obesity and immune function (Banni et al. 2002).

As regards the summer cheese, it was lower in SFA, especially in medium-chain SFA (C12:0 and C14:0), which tends to increase cholesterol and LDL in humans (Hornstra 1999; Hu et al. 2001).

Table 6 Canonical discriminant analysis: correlations between canonical and original variables of 18 cheeses

In italics the items that more characterize the canonical variables

\begin{tabular}{lcc}
\hline Variable & $\begin{array}{l}\text { 1st canonical } \\
\text { variable }\end{array}$ & $\begin{array}{l}\text { 2nd canonical } \\
\text { variable }\end{array}$ \\
\hline Total mesophilic count & -0.144 & -0.527 \\
Enterococci & -0.162 & -0.219 \\
Thermophilic coccus LAB & -0.569 & -0.287 \\
Mesophilic coccus LAB & -0.139 & -0.303 \\
Mesophilic rod coccus & 0.212 & 0.217 \\
Dry matter & 0.412 & -0.498 \\
Fat & -0.329 & 0.549 \\
Protein & -0.094 & 0.632 \\
Salt & 0.386 & -0.028 \\
Ash & -0.061 & 0.184 \\
$\sum_{\text {SFA }}$ & 0.655 & -0.026 \\
$\sum$ MUFA & -0.723 & -0.393 \\
$\sum$ PUFA & -0.388 & 0.294 \\
Variance explained (\%) & 86 & 14 \\
\hline
\end{tabular}


Although the total amount of PUFA did not differ significantly by season, the summer cheese was particularly high in linoleic acid (C18:2 n-6) and thus in the omega-6/omega-3 ratio. As the FA profile of wheat grains comprises more than $57 \%$ linoleic acid (Nikolić et al. 2008), this result can be due to a greater intake of remaining grains by ewes grazing in the residues of wheat crops after threshing. However, with regard to linoleic acid, a lower rate of biohydrogenation, linked to variations in the rumen environment, can also play a role (Chilliard et al. 2001).

Moreover, the increase in MUFA, especially oleic acid (C18:1 c9), observed in the summer and autumn cheese was unexpected and was presumably a result of the mobilisation of long-chain FA, particularly oleic acid, from the body fat deposits of the ewes (Chilliard et al. 2003). The purpose of this mobilisation is to balance the energy deficits that ewes incur more frequently in summer and autumn, when the feeding regime may not be sufficient to satisfy their energy needs.

On the whole, these results reveal that the FA profile of cheese produced in summer, when ewes are fed without green forage, maintains some beneficial properties for human health, as confirmed by the higher Health-Promoting Index.

Data on the cheese were also analysed using a multivariate approach. Canonical discriminant analysis, performed simultaneously on microbiological, chemical and FA composition, clearly differentiated the Vastedda cheese produced in the different seasons. A plot of the first canonical variable ( $y$-axis) and the second canonical variable ( $x$-axis) showed the cheese produced in summer at the bottom, that produced in autumn in the centre, and that produced in spring at the top (Fig. 2). However, the Mahalanobis distance between the centromeres of the point clouds was statistically significant only for cheese produced in summer and spring (Table 5). The canonical correlation coefficients (Table 6) showed that this distinction was mainly due to the first canonical variable, which explained $86 \%$ of the variance, especially for the negative correlation with MUFA and thermophilic lactococci and the positive correlation with SFA, which confirms the effects of the ewes' feeding regime and the environment of milk production and cheese manufacture in determining cheese quality. With regard to the second canonical variable, which explained only $14 \%$ of the variance, the total mesophilic count (negatively related) and the fat and protein content (positively related) contributed more than the other constituents, with higher correlation coefficients.

\section{Conclusions}

The results of this investigation show the change in the quality of milk from Valle del Belice ewes over the year, as is typical in farming systems based on grazing pasture, and the characteristics of milk and cheese produced in summer compared with that produced in the rest of the year.

Summer milk had higher fat and casein contents, which are relevant for cheese yield. The higher TBC level and weaker clotting ability did not prevent the milk from being used in the processing of cheese during the summer. In addition, the FA profile of the summer cheese was beneficial for human health because of the lower SFA content and the increased MUFA, linoleic acid and omega-3 FA.

These results support the production of summer cheese, especially PDO Vastedda della valle del Belice cheese, from the milk of Valle del Belice ewes. However, 
adequate management and feeding regimes must aim to prevent the effects of heat stress and nutritional deficiencies to further enhance the yield and quality of milk and cheese produced in the hot summer months.

\section{References}

Albenzio M, Taibi L, Muscio A, Sevi A (2002) Prevalence and etiology of subclinical mastitis in intensively managed flocks and related changes in the yield and quality of ewe milk. Small Rumin Res 43:219-226

Albenzio M, Santillo A, Caroprese M, D'Angelo F, Marino R, Sevi A (2009) Role of endogenous enzymes in proteolysis of sheep milk. J Dairy Sci 92:79-86

Antongiovanni M, Buccioni A, Petacchi F, Secchiari P, Mele M, Serra A (2003) Upgrading the lipid fraction of foods of animal origin by dietary means: rumen activity and presence of trans fatty acids and CLA in milk and meat. Ital J Anim Sci 2:3-28

Banni S, Murru E, Angioni E, Carta G, Melis M (2002) Conjugated linoleic acid isomers (CLA): good for everything? Sci Aliment 22:371-380

Bauman DE, Mather IH, Wall RJ, Lock AL (2006) Major advances associated with the biosynthesis of milk. J Dairy Sci 89:1235-1243

Bianchi L, Bolla A, Budelli E, Caroli A, Casoli C, Pauselli M, Duranti E (2004) Effect of udder health status and lactation phase on the characteristics of Sardinian ewe milk. J Dairy Sci 87:241-2408

Bonanno A, Di Grigoli A, Tornambè G, Bongarrà M, Alicata ML (2005) Gli ovini al pascolo sulle stoppie producono più latte [Sheep grazing on stubble produce more milk]. L'Informatore Agrario 50:46-49

Bonanno A, Todaro M, Di Grigoli A, Scatassa ML, Tornambè G, Alicata ML (2008) Relationships between dietary factors and milk urea nitrogen level in goats grazing herbaceous pasture. Ital J Anim Sci 7:219235

Cabiddu A, Decandia M, Addis M, Piredda G, Pirisi A, Molle G (2005) Managing Mediterranean pastures in order to enhance the level of beneficial fatty acids in sheep milk. Small Rumin Res 59:169-180

Cannas A, Pes A, Mancuso R, Vodret B, Nudda A (1998) Effect of dietary energy and protein concentration on the concentration of milk urea nitrogen in dairy ewes. J Dairy Sci 81:499-508

Cappio-Borlino A, Portolano B, Todaro M, Macciotta NPP, Giaccone P, Pulina G (1997) Milk, fat and protein lactation curves of Valle del Belice dairy sheep estimated with Test Day Models. J Dairy Sci 80:30233029

Carta A, Sanna SR, Casu S (1995) Estimating lactation curves and seasonal effects for milk, fat and protein in Sarda dairy sheep with a test day model. Livest Prod Sci 44:37-44

Chen S, Bobe G, Zimmerman S, Hammond EG, Luhman CM, Boylston TD, Freeman AE, Beitz DC (2004) Physical and sensory properties of dairy products from cows with various milk fatty acid compositions. J Agric Food Chem 52:3422-3428

Chilliard Y, Ferlay A, Doreau M (2001) Effect of different types of forages, animal fat or marine oils in cow's diet on milk fat secretion and composition, especially conjugated linoleic acid (CLA) and polyunsaturated fatty acids. Livest Prod Sci 70:31-48

Chilliard Y, Ferlay A, Rouel J, Lamberet G (2003) A review of nutritional and physiological factors affecting goat milk lipid synthesis and lipolysis. J Dairy Sci 86:1751-1770

Dewhurst RJ, Scollan ND, Lee MR, Ougham HJ, Humphreys MO (2003) Forage breeding and management to increase the beneficial fatty acid content of ruminant products. Proc Nutr Soc 62:329-336

Di Grigoli A, Todaro M, Di Miceli G, Alicata ML, Cascone G, Bonanno A (2009) Milk production and physiological traits of ewes and goats housed indoor or grazing at different daily timing in summer. Ital $\mathrm{J}$ Anim Sci 8(suppl 2):616-618

Finocchiaro R, Van Kaam JBCHM, Portolano B (2007) Effect of weather conditions on somatic cell score in Sicilian Valle del Belice ewes. Ital J Anim Sci 6(suppl 1):130-132

Fthenakis GC (1994) Prevalence and aetiology of subclinical mastitis in ewes of Southern Greece. Small Rumin Res 13:293-300

Fuertes JA, Gonzalo C, Carriedo JA, San Primitivo F (1998) Parameters of test day milk yield and milk components for dairy ewes. J Dairy Sci 81:1300-1307

Giaccone P, Todaro M, Portolano B (2004) Analysis of milk production of Valle del Belice ewes reared in their area of origin and analysis of expansion of the breed. Agric Med 134:246-250

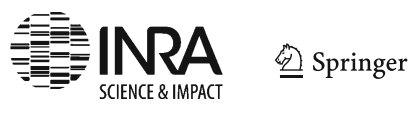


Hornstra G (1999) Lipids in functional foods in relation to cardiovascular disease. Lipids 12:S456-S466

Hu FB, Manson JE, Willett WC (2001) Types of dietary fat and risk of coronary heart disease: a critical review. J Am Coll Nutr 20:5-19

IDF (1964a) Determination of the casein content of milk. International Standard FIL-IDF No. 29. Int Dairy Fed, Brussels, Belgium

IDF (1964b) Determination of the protein content of processed cheese products, International Standard FILIDF No. 25. Int Dairy Fed, Brussels, Belgium

IDF (1964c) Determination of the ash content of processed cheese products, International Standard FIL-IDF No. 27. Int Dairy Fed, Brussels, Belgium

IDF (1972) Cheese-determination of chloride content, International Standard FIL-IDF No. 17A. Int Dairy Fed, Brussels, Belgium

IDF (1982) Cheese and processed cheese product, Determination of the total solids content. Standard FIL-IDF No. 4A. Int Dairy Fed, Brussels, Belgium

IDF (1986) Cheese and processed cheese product, Determination of fat content-gravimetric method (reference method). International Standard FIL-IDF No. 5B. Int Dairy Fed, Brussels, Belgium

IDF (1990) Determination of milk fat, protein and lactose content - Guide for the operation of mid-infra-red instruments. International Standard FIL-IDF No. 141B. Int Dairy Fed, Brussels, Belgium

IDF (1993) Determination of total nitrogen in milk, International Standard FIL-IDF No. 20B. Int Dairy Fed, Brussels, Belgium

IDF (1995) Enumeration of somatic cells. International Standard FIL-IDF No. 148A. Int Dairy Fed, Brussels, Belgium

Jaramillo DP, Zamora A, Guamis B, Rodrìguez M, Trujillo AJ (2008) Cheesemaking aptitude of two Spanish dairy ewe breeds: changes during lactation and relationship between physico-chemical and technological properties. Small Rumin Res 78:48-55

Jonker JS, Kohn RA, Erdman RA (1999) Milk urea nitrogen target concentrations for lactating dairy cows fed according to National Research Council recommendations. J Dairy Sci 82:1261-1273

Kalantzopoulos G (1994) Influence of somatic cells on milk and dairy products quality. In: Proceedings of the International Symposium on Somatic Cells and Milk of Small Ruminants, Bella, September 25-27, 1994, pp. 281-290

Loor JJ, Herbein JH, Polan CE (2002) TranS18:1 and 18:2 isomers in blood plasma and milk fat of grazing cows fed a grain supplement containing solvent-extracted or mechanically extracted soybean meal. J Dairy Sci 85:1197-1207

Maria G, Gabina D (1993) Non-genetic effects on milk production of Latxa ewes. Small Rumin Res 12:61-67

Matutinovic S, Kalit S, Salajpal K, Vrdoljak J (2011) Effects of flock, year and season on the quality of milk from an indigenous breed in the sub-Mediterranean area. Small Rumin Res 100:159-163

Morgante M, Ranucci S, Pauselli M, Casoli C, Duranti E (1996) Total and differential cell count in milk of primiparous Comisana ewes without sign of mastitis. Small Rumin Res 21:265-271

Mucchetti G, Bonvini B, Remagni MC, Ghiglietti R, Locci F, Barzaghi S, Francolino S, Perrone A, Rubiloni A, Campo P, Gatti M, Carminati D (2008) Influence of cheese-making technology on composition and microbiological characteristics of Vastedda cheese. Food Control 19:119-125

Nikolić N, Radulović N, Momcilović B, Nikolić G, Lazić M, Todorovic Z (2008) Fatty acids composition and rheology properties of wheat and wheat and white or brown rice flour mixture. Eur Food Res Tech 227: 1543-1548

Nousiainen J, Shingfield KJ, Huhtanen P (2004) Evaluation of milk urea nitrogen as a diagnostic of protein feeding. J Dairy Sci 87:386-398

Nudda A, McGuire MA, Battacone G, Pulina G (2005) Seasonal variation in conjugated linoleic acid and vaccenic acid in milk fat of sheep and its transfer to cheese and ricotta. J Dairy Sci 88:1311-1319

Parodi PW (1999) Conjugated linoleic acid and other anticarcinogenic agents of bovine milk fat. J Dairy Sci 82:1339-1349

Peana I, Fois G, Cannas A (2007) Effects of heat stress and diet on milk production and feed and energy intake of Sarda ewes. Ital J Anim Sci 6(suppl 1):577-579

Pulina, G., Nudda, A. (2002) Milk production. In: Pulina G. (ed), Dairy Sheep Feeding and Nutrition, Avenue Media, Bologna, Italy, pp. 11-27

Pulina G, Nudda A, Battacone G, Cannas A (2006) Effects of nutrition on contents of fat, protein, somatic cells, aromatic compounds, and undesirable substances in sheep milk. Anim Feed Sci Technol 131:255291

SAS (2010) SAS/STAT Qualification Tools User's Guide (version 9.2). Statistical Analysis System. Institute Inc, Cary, NC, USA 
Schepers AJ, Meijer RGM (1998) Evaluation of the utilization of dietary nitrogen by dairy cows based on urea concentration in milk. J Dairy Sci 81:579-584

Sevi A, Albenzio M, Taibi L, Dantone D, Massa S, Annicchiarico G (1999) Changes of somatic cell count through lactation and their effects on nutritional renneting and bacteriological characteristics of ewe's milk. Adv Food Sci 21:122-127

Sevi A, Taibi L, Albenzio M, Muscio A, Annicchiarico G (2000) Effect of parity on milk yield, composition, somatic cell count, renneting parameters and bacteria counts of Comisana ewes. Small Rumin Res 37:99107

Sevi A, Albenzio M, Marino R, Santillo A, Muscio A (2004) Effects of lambing season and stage of lactation on ewe milk quality. Small Rumin Res 51:251-259

Zannoni M, Annibaldi S (1981) Standardization of the renneting ability of milk by Formagraph. Sci Tecn Lattiero-Casearia 32:9-24 